\title{
The beginning of life of a new human being from the scientific biological perspective and its bioethical implications**
}

\author{
Patricio Ventura-Juncá (1) and Manuel J. Santos (2) \\ (1) Centro de Bioética y Departamento de Pediatría, Facultad de Medicina, Pontificia Universidad Católica de Chile (2) Departamentos de Biología Celular y \\ Molecular y Pediatría, Facultades de Ciencias Biológicas y Medicina, Pontificia Universidad Católica de Chile, Santiago, Chile.
}

\begin{abstract}
The issue of when the human life begins is a very important subject since it has a significant impact on the decisions that we have to take in relation to human beings in development, particularly human embryos. In this article we discuss some of the more relevant biological evidence supporting the fact that beginning human life begins unquestionably at fertilization and the bioethical consequences.
\end{abstract}

Key words: fertilization, beginning of human life, bioethics.

\section{INTRODUCTION}

The process of generating a new human being has always been the object of particular fascination for philosophers and scientists throughout our history. Today, without doubt, the issue has acquired new dimensions given that we have acquired the capacity to intervene in life at its beginnings in ways that could not have been anticipated a few decades ago, which is of great scientific, anthropological and ethical importance. The decisions that we take with respect to human beings in development, particularly in relation to intervention against human embryos are today the subject of debate. For example, the biomedical advances related to in vitro fertilization, pre-implantation diagnosis, genetic engineering, human cloning (Santos, 2005), the use of maternal embryonic cells (Ventura-Juncá, 2009) and emergency contraceptives are procedures that make the contemporariness and importance of the issue very evident.

To have a lucid debate it is necessary to identify precisely what are the key questions that require an interdisciplinary approach, considering biology, anthropology and ethics. The question of when human life begins is for the field of biology. The question of whether every "human being" is morally relevant and consequently worthy of the respect owing to a human person is for the competence of anthropology and ethics. Conscious that we can distinguish, but not totally separate these areas, in this article we address the biological aspects, which are fundamental for a consistent philosophical reflection and we address the main bioethical questions involved.

\section{SOME HISTORY}

The beginning of life in Greek medical and philosophical writings

The process of generating a new human individual has long intrigued philosophers and biologists. There are several texts of the Hippocratic Corpus (Hippocratic Writings, 1983) that refer to the theme, and the observations of Aristotle in several of his writing, among them notably his famous study on "The Generation of Animals" (Aristotle, 1953).

While the facts show that the generation of a new individual emerges from sexual relations between a man and a woman, a series of questions arose that biologists and philosophers tried to answer, such as: What is the contribution of the man and the woman in the process of generation? What does the contribution of each one consist of? Is there a masculine semen (seed) and another that is feminine? How do the masculine and feminine seeds come together and interact? How do we explain the similarity between children and parents? Why is a girl born sometimes and a boy another time? What influence does the environment have on the development and the characteristics of the new individual?

The scarce biological knowledge of the epoch based on certain elemental observations resulted in theories and answers to these questions in which imagination far exceeded empirical observation. An example of this is the Aristotelian explanation of the role played by semen and menstrual flow in the development of a new individual. Aristotle, in contrast to the Hipocraticans, considered that masculine contribution through the semen was the efficient cause in the process of generation and that the female contribution came from menstrual flow as the material cause. This vision fits very well with the hylemorphic theory of the four causes (final, efficient, formal and material), which explains movement. Aristotle proposed that human life began when fetal movement is detected, which is a theory called progressive animation that was later adopted by Thomas Aquinas. The reflections of Aristotle and Aquinas were based on very rudimentary biological knowledge. What is surprising is that even at the present time there are individuals who maintain this argument in the framework of current biological knowledge.

The invention of the microscope permitted the discovery of gametes (Farley, 1982)

The invention of the microscope by Zacharias Jansen at the end of the $16^{\text {th }}$ century was decisive for the advance of knowledge

Corresponding author: Manuel J. Santos, Departmentos de Biología Celular y Molecular y Pediatría, Facultades de Ciencias Biológicas y Medicina, Pontificia Universidad Católica de Chile, Casilla 114-D, Santiago, Chile, Tel: (562) 686 2835; Fax (562 686 2833), email: msantos@bio.puc.cl

** A tribute to Prof. Dr. Claudio Barros, Chilean biologist who was an expert in Embryology and Developmental Biology and their bioethical implications. 
about the process of reproduction. It made the discovery of gametes possible. In 1677, Anton van Leeuwenhoek, a great microscopist, described spermatozoid in masculine semen in a letter sent to the Royal Society de London on 1677. He termed the spermatozoid animaculae. In 1827, the embryologist Kart Ernst Von Baer discovered the ovum, first of a dog and then in other mammals. The animaculae or spermatozoids discovered by Leeuwenhoek were considered parasites of the semen in a larval state.

The preformists animaculists (17 th century) ovist theories (18 $18^{\text {th }}$ century) and epigenetics

Although the true role of the ovum and sperm in reproduction was far from having been elucidated, their discovery led to the emergence of preformist theories, which responded to the ancient question: How can we explain the development of all the parts of an organism from a seed? It was necessary that in some manner these parts were present in the seed. Preformist theories can be divided into two groups: the animaculistas and the ovists. As Needham summarized: "The ovists considered that the complete embryo developed based on a small embryo found in the unfertilized egg. On the other hand, the animaculistas considered that the complete embryo is produced from a small embryo that is provided by the male sperm" (Needham, 1959). Preformist theories were refuted by various scientists, among them notably Carl Linnaeus (17071778) who gave solid arguments to affirm that "descendance does not come from the egg nor from semen alone" but rather from both (Linnaeus, 1766). The epigenists were opposed to the preformists, believing that life began from an unformed mass that develops and differentiates because of internal and external forces.

The discovery of the role of gametes, the first description of the fertilization process, the cellular theory and the discovery of chromosomes

These discoveries were made almost simultaneously during the $19^{\text {th }}$ century, in part as the result of improvements in the production of microscopes and staining techniques. In his famous experiment, Lázaro Spallanzani (1729-1799) demonstrated that if semen were filtered, it lost its fertilizing capacity, but still did not discover the role of the spermatozoids and continue to believe they were parasites. Jean-Louis Prevost (1790-1850) and Jean-Baptiste Dumas (1800-1884) showed that spermatozoids were not parasites and that their contact with the ovum was essential for fertilization (Prévost and Dumas, 1824). In 1852, Nelson was the first to report having viewed spermatic particles in ascaris ovum: "the present research appears to be the first in which the fact of the penetration of the spermatozoid in the ovum has been clearly seen and established" (Nelson, 1852). In 1853 Newport reported having seen spermatozoids in frogs eggs (Newport, 1853). A year later, Bischoff confirmed the fact: "There cannot be any more doubt that the spermatozoid really penetrates the frog egg" and proposed that this would be valid for the eggs of mammals as well (Bischoff, 1854).

Another key fact to clarify fertilization was the development of cellular theory by Matthias Schleiden (18041881) and Theodor Schwann (1810-1882). The first described cells in plants and the second in animals. Schwann postulated that the ovum described by von Baer was probably a cell
(Schwann, 1874). Walter Flemming (1843-1905) developed the concept of mitosis in cellular division that begins with the division of the nucleus (Flemming, 1880). He was credited, along with Boveri (1862-1915) and Weissmann (1834-1914), for the discovery of the chromosomes. In 1874, Leopold Auerbach (1828-1897) reported having observed the presence of pronuclei in the fertilized egg, which then fused to form the nucleus of the zygote (Auerbach, 1874). Impressed by these findings, Hertwig argued, "The nucleus of the zygote is the result of the joining of the nuclei of the masculine and feminine gametes". Van Beneden and Boveri showed that for this to occur there had to be an equal contribution of chromosomes on the part of the ovum and the sperm and that each had to contribute half of the nucleus so that the new nucleus of the zygote maintained the number of chromosomes (Bovari, 1890; Van Beneden, 1883). He wrote to Hertwig and Weissmann to explain and show the process of meiosis, by means of which the precursor cells of the gametes converted into haploid cells, that is with only 23 chromosomes compared to the 46 that other cells have (Hertwig,1890; Weismann,1891). With this, a fundamental cycle in understanding the process of fertilization was complete.

\section{Concepts about conception and fertilization}

Since the first reflections about the process of generation, conception was understood as the moment in which the life of a new organism or individual of a species begins. However, the biological knowledge and understanding about when and how this event was produced was only acquired with the discoveries described above, which culminated in the description and study of the penetration of the ovum by the spermatozoid, resulting in a new cell, the zygote. This process has been termed fertilization and represents the initiation of the life of a new human individual. The conception of a new human being thus occurs with fertilization. Ernst Haeckel, a materialist evolutionist, recognized this fact: "While we should consider the spermatozoid as a cell as real as the ovum, and the process of conception as the fusion of both, we should consider the resulting cell as a new and independent organism. The mixture of the two cells is the germ of the child or the new organism that has been conceived" "The recognition that every man begins his individual existence as a simple cell is a solid basis to investigate the genesis of man" (Haeckel, 1876).

\section{THE DEVELOPMENT OF MODERN GENETICS AND EMBRIO- LOGY AND THEIR INTEGRATION INTO DEVELOPMENTAL BIOLOGY: FERTILIZATION}

Genetics and epigenetics

The discovery of the nucleus, of chromosomes, the works of Mendel on the inheritance of maternal and paternal characteristics and the fact that all the cells of a species have the same number of chromosomes were central milestones in the history of genetics. These findings were crucial for understanding the process of generation of a new human being.

The content of the genetic material present in each human cell is termed the genome. This is chemically composed of DNA (deoxyribonucleic acid), which is a simple molecule and similar to a doubled spiral stairway in the shape of a helix. The discovery of the molecular structure of the double helix of DNA 
(Watson and Crick, 1953a) was key for further development in this field. The authors envisaged that this discovery would lead to explaining the process of replicating genetic matter (Watson and Crick, 1953) and would give an unsuspected power to intervene in the molecular basis of life and heredity.

Each string of the double strand of DNA is formed by subunits called nucleotides formed by sugar molecules (desoxyribose) bonded to phosphate molecules by nitrogenated bases. There are four nitrogenated bases in DNA: A (adenine); G (guanine); T (thymine) y $\mathrm{C}$ (cytosine). A always bonds with $\mathrm{T}$, and $\mathrm{G}$ always bonds with $C$, so that there are always two types of bridges: A-T and G-C. DNA is an extraordinarily simple molecule that nevertheless contains all the genetic information of an organism. This genetic information resides in a particular order (or sequencing) of the nucleotides in the DNA. Genes are discrete segments of DNA that have information to synthesize a product (especially proteins). The human genome contains the nuclear and mitochondrial genome. The nuclear genome is distributed over 46 human chromosomes and has around 25,000 genes and 3.2 billion nucleotides (Lander, 2011). The Human Genome Project has provided information about the sequencing of the whole nuclear genome and more than 21.000 genes of known functions.

(http:/ / www.ornl.gov/sci/techresources/Human_Genome/ home.shtml). The mitochondrial genome, which is found in the cytoplasm with the mitochondrion (energy factories), is much smaller (37 genes and 16,000 nucleotides) and is transmitted by the mother through the ovum.

The most recent advances in genetics have corroborated with increasingly more precise information that the life of a new individual begins with the union of two highly specialized haploid cells (each with 23 chromosomes), the spermatozoid and the ovum, which give rise to a new cell when they are joined: the zygote. The zygote contains a new genetic code with 46 chromosomes. An individual and unique set of genes arises representing the beginning of the life of a new human organism, or in effect, a new individual or human being. It is thus all the cells of a human being come from an original cell, the zygote. The zygote has a new genetic structure, distinct from that of the ovum and of the spermatozoid, distinct from those of the parents. This new genome, whose fundamental structure will be maintained throughout the development, indentifies the unicellular embryo as biologically human. It is relevant to clarify the difference between what is a cell and what is an organism, including in its unicellular stage (Carrasco and Ventura-Juncá, 2010). Aristotle provided a notable definition of an organism that included the concept of integrated workings of the parts of living animals in function of the whole: "the animal organism must be conceived after the similitude of a well-governed commonwealth" (Aristotle, 2000). There is general consensus that the condition of the organism supposes a living being that functions in an organized and integral manner, such that the whole is greater than the sum of its parts (Hurlbut et al. 2006). Austríaco integrated the philosophical and biological perspectives in a definition of the concept: "Philosophically, an organism can be defined as a complete living substance, with its own internal principle of movement and change, that directs it toward its natural perfection; and scientifically, as a discrete unit of living matter that from itself continues a path of robust development, which in turn manifests the specific self-organization of its species" (Austriaco, 2006). Goodwin has a similar conception (Goobwin, 1993).

With fertilization and the formation of the zygote, the life of a new individual in the human species begins, with an ongoing and predictable development that ends in the complete formation of the organism. This development is directed at its beginnings from within the zygote.

The observably normal and pathological biological characteristics of a human being are determined by the genes present in the nuclear and mitochondrial genome inherited from both parents and from environmental conditions that influence development. There are factors not found in the genes that are capable of influencing gene expression and function. These can be within the organism during development or can come from the external environment. These factors have been termed epigenetic factors. The development of a new individual is thus a complex process in which genetic and epigenetic factors intervene (Bedregal et al. 2010).

With all the excitement that knowledge about the human genome has provoked, there is the danger of considering that all the biological characteristics of human beings are located only in their genes (genetic reductionism) and that they determine such characteristics (genetic determinism). The irruption of epigenetic factors mentioned above has demonstrated that genes need to interact among themselves and with their environment in order to develop their potential (Newman, 2005). During embryonic development, activation and silencing of different specific genes are produced in determined stages of embryonic development: certain genes in determined cells are silenced and other genes are activated. This is achieved through molecular mechanisms that do not alter the sequence of genes involved and these changes in gene expression (in this case silencing) are inherited through cellular division. Given that this is not a matter of mutation, that is, a change that affects the gene sequence (there is no mutation), this can be reversible. These hereditary changes that do not involve DNA sequencing are termed epigenetic changes or epimutations. The term epigenetic was coined by Waddington in 1939, who defined it as "the study of all the events that lead to the unfolding of the program of genetic development". Epigenetics is currently defined as "the study of changes in the function of genes that are inheritable through mitosis and/or meiosis, that do not involve a modification of DNA sequencing and can be reversible." $(\mathrm{Wu}$ and Morris, 2001). The term epigenome refers to the genome with the molecular changes that modify gene expression. As a complement to the Human Genome Project, there is currently the Human Epigenome Project (Bradbury, 2003). The most studied molecular mechanisms involved in gene silencing are: DNA methylation (methylation of the cytosine base, which affects gene expression); chemical modification of histones (proteins that envelope the DNA and that can acquire diverse chemical groups, change their conformation, producing a greater or lesser degree of compacting of the DNA and thus changing gene expression) and silencing by non-coding RNA (ncRNA), such as RNA interference (RNAi) whose inhibiting RNA can destroy messenger RNAs and produce the absence of the respective protein. Recently, new epigenetic mechanisms have been described, such as: positive feedback, in which a system is activated in a cell that does not produce a determined protein in order to initiate its production and exacerbate the protein production over time; and protein aggregation, in which conformational changes of proteins results in their aggregation and this condition can be inherited from one cellular generation to new generations. The importance of epigenetics in the development and understanding of diseases is one of the most relevant aspects of Biology in the $21^{\text {st }}$ century (Feinberg, 2008). The genetic and epigenetic factors are integrated in the fundamental equation of a new organism: GENOTYPE 
(Genome + Epigenome) + ENVIRONMENT -------> PHENOTYPE: In effect, the complete phenotype is the result of a genotype that is expressed in a determined environment and the interactions between them. In other words, the genome is not sufficient to produce the normal and pathological characteristics of human beings (Santos, 2006).

\section{Embryology}

By the middle of the $20^{\text {th }}$ century, the discoveries in embryology and genetics had elucidated many of the central questions about the generation of a new individual. The results of descriptive and experimental embryology in relation to the beginning of life have been described by distinguished researchers and are found in various texts (Carlson, 1994; Larsen, 1993; Moore and Persaud, 1993). Sadler stated: “The development of an individual begins with fertilization, a phenomenon in which a spermatozoid of the man and the ovum of a woman join to give rise to a new organism, the zygote" (Sadler, 2000). In his Developmental Biology book, Scott Gilbert dedicated a chapter to the theme entitled "Fertilization; Beginning a New Organism" (Gilbert, 2006). A recent book on molecular biology states: "Every human being begins as a zygote, which houses all the necessary instructions for building a human body containing about 100 trillion (1014) cells, an amazing feat" (Lodish et al. 2008). Much more is known today about the genetic and epigenetic processes in fertilization at the functional and molecular levels (Hemberger et al, 2009). At the same time, the harmonious and systematic way that the events unfold inspires admiration and we discover that understanding the complexity of the process still lives many unanswered questions.

\section{Fertilization}

Fertilization is a process that begins with the fusion of the membranes of the spermatozoid and the ovum. This occurs in the fallopian tube and forms the zygote, which is the first stage in the development of a new human being. In the understanding of the process, our honored Professor Claudio Barros made contributions of recognized importance (Barros and Austin, 1967; Barros and Franklin, 1968; Barros et al. 1996; Franklin et al. 1970). These contributions attracted the attention of the international scientific community. The following commentary can be found in the web site: http: / / www.educarchile.cl / Portal.Base / Web / VerContenido. aspx?ID=76402. "In 1968 Doctor Claudio Barros, academic and researcher of Universidad Católica de Chile, published the first work in the world that showed the way in which gametic fusion in mammals is produced, in effect, the fusion of spermatozoid and the ovum. The eyes of the international scientific community turned toward our country and we were something like world champions in the biological sciences". In his own words, Dr. Barros said of this work: "Our work showed for the first time that the spermatozoid and the egg in mammals are two cells that come together and fuse into only one, the zygote. This holds true for all mammals, including humans. We also discovered that the spermatozoid does not enter the egg at a point but rather places itself along side. Today, although more than 30 years have passed since this discovery, the majority of textbooks continue with the same error of saying that the sperm enters from the front. But to me, the most important thing was to clearly establish that the zygote is formed in this moment, a few minutes after the spermatozoid has make contact with the egg. Many subsequent studies have ratified our findings, in a way that has left me very satisfied to have contributed a grain of sand to this new knowledge at the world level". These landmark findings have been confirmed by numerous other investigations (Gadella and Evans, 2011; Primakoff and Myles, 2002).

Fertilization unites the ovum, whose pronucleus contains the 23 maternal chromosomes and the spermatozoid that contributes 23 chromosomes in the paternal nucleus. Both chromosome sets have epigenetic changes (essentially different degrees of methylation). These epigenetic changes, termed genetic imprinting, are complementary and required to biologically generate human beings. The maternal mitochondria contribute their genome to constitute the genome of the zygote. By successive divisions and differentiation, the zygote forms each of the cells present in the embryo, fetus, newborn, child and adult.

The zygote is different from any other cell of the human organism. As Haeckel said more than a century ago, it is a new organism (Haeckel, 1876). There is no doubt that for the biologist the zygote has a new genetic structure, different from that of the ovum and of the spermatozoid, different from those of the parents. The first stage of the development of a new human being begins with this. It is an ongoing and predictable development that continues until the complete formation of the organism. This development is directed from its beginning from within the zygote. It is not controlled from outside by the mother, but rather is determined by the beginning by the new genetic code inscribed on the zygote from the moment of fertilization and active since the first moments. This discovery is considered one of the key milestones in the advance of developmental biology and merited the Nobel Prize for Medicine to Drs. Edward B. Lewis, Christiane NüssleinVolhard and Eric F. Wieschaus for their discovery of the genetic control of early embryonic development. The work of these developmental biologists established the genetic mechanisms that regulate the first stages of the development of the embryo of the fruit fly, but as the official announcement for the awarding of the Nobel Prize in 1995 indicated "the principles found in the fruit fly apply also to higher organisms, including man" http:/ / nobelprize.org/medicine/laureates/1995/ press. html

The zygote has a new genetic code different from that of the father and mother, that is, a genetic combination with a qualitatively new program of instructions. It is a new genome whose fundamental structure will be maintained throughout the development, which identifies unicellular embryo as a biologically human individual (Burgess, 2008).

\section{Early events of fertilization}

After the fusion of the membranes of the spermatozoid and the ovum, a series of biological events begin that triggers embryonic development and that start with a series of interactions between the ovum and the spermatozoid, which enters the maternal cytoplasm (Barros et al. 1966; Evans and Florman, 2002; Plachot, 2000; Sutovsky, 2009). Among these interactions are the contributions of the maternal proteome (a set of cellular proteins) and its effect on the structures derived from the spermatozoid. It should be noted that in fertilization the spermatozoid completely enters the ovum, that is, the head (containing the pronucleus and the centriole), the intermediate 
segment (containing the paternal mitochondrion) and the tail (containing the flagellum). The paternal mitochondria are destroyed in the cytoplasm of the zygote, so that all human mitochondrion (and the mitochondrial genome) are of maternal origin ((Sutovsky et al. 1999; Sutovsky et al. 2004).

Among the first biochemical findings temporally related to fertilization are notably: a major flow of ions toward the ovum (especially $\mathrm{Ca}+2)$ (Whitaker, 2006), changes in the electrical charge of the membrane of the ovum, morphological changes of the paternal nucleus (disintegration of the nuclear envelope, chromatin decondensation), the exchange of proteins present in the DNA in the paternal nucleus (protamines) by the histones present in the cytoplasm of the ovum, the synthesis separately of the DNA in each maternal and paternal pronucleus (without syngamy occurring, as in the case of amphibians (Eddy and Shapiro, 1979; Ramalho-Santos, 2002). After fertilization and during the maternal-zygote transition phase (MZT) (Schultz, 1993); the maternal transcripts are degraded (RNAm) to give way for the transcription of the genome of the embryo, which can begin to be expressed within a few hours after fertilization (Ao et al. 1994; Daniels et al. 1997, Fiddler et al. 1995). The activation of the genome of the zygote (embryo), is the consequence of the reprogramming of the pattern of expression of the genes in the zygote, in effect, the generation of changes in the epigenetic state at the level of DNA methylation and chemical modifications of the histones (Hemberger et al., 2009; Feil, 2009; Ikegami et al. 2009). All this scientific evidence confirms that at the moment of fertilization, the functioning of a new human organism begins.

Subsequently, around 30 hours after fertilization, the first division of the zygote generates the first two cells, which are termed blastomeres. Each blastomere has 46 chromosomes and has the capacity of reprogramming itself and originating a complete human being if it were separated from the embryo, whether artificially in vitro or spontaneously as occurs in the case of identical twins (or monozygotic non-identical twins). In effect, the blastomeres are potentially totipotential cells. It is important to point out that as Hemberger explains "the zygote is the only unequivocally totipotent cell in the life cycle". (Hemberger et al. 2009). According with this statement, it has been shown that these potentially totipotential cells have a certain destiny. Dr. Magdalena Zernicka-Goetz and Dr. Richard Gardner have shown that the development of mammals is completely regulated and that the basic plan of the embryo begins to establish itself after fertilization. Consequently, the destiny of the mammalian embryo is established from the first moment of development (Zernicka-Goetz, 2005). This raises a question about the safety of the pre-implantation genetic diagnosis in which a blastomere is removed. Each blastomere then divides in two and then each divides in two again. At the stage of four or eight cells, the genome of the embryo begins to express itself more massively, that is to say, an epigenome is configured - a genome with a series of changes in the pattern of expression that is inherited throughout the embryonic divisions. At three days the embryo is full of cells (blastomere) and resembles a berry and is termed a morula. From the stage of two blastomeres until the morula stage, it is currently possible to make a pre-implantation genetic diagnosis of human embryos obtained from in vitro fertilization. To do this, a biopsy is performed to obtain a blastomere to in turn obtain the DNA and carry out molecular genetic diagnoses to select the embryos to be implanted. At the fourth or fifth day the embryo grows and a cavity is generated, producing a blastocyst. Cellular territories appear in the blastocyst destined to specific functions. The internal cellular mass of the blastocyst has pluripotential stem cells that are responsible for producing the cells of different tissue of the human embryo. At the seventh day after fertilization, the embryo reaches the uterus where it is implanted and begins the production of hormones, the detection of which in laboratory tests allows for confirming pregnancy.

Around 14-16 days gastrulation begins, which originates the different organs of the fetus. It is interesting to note that until day 16, it is possible that the embryo divides and produces Siamese twins (Smith and Brogaard, 2003). Another important embryological milestone is the appearance of the neural groove around day 14, which is considered the first indication of the future central nervous system.

The maternal-embryo pre-implantation dialogue: Preparation for implantation

During the stage from fertilization to implantation, as we have related, the embryo multiplies and begins its organization with the formation of the axis of the body and the orientation of the destiny that the first cells will have. Recent research has shown that at this stage communication is established with the mother, which is necessary for implantation and future development (Singh et al. 2011). While these discoveries have been made basically with rats, there is consensus that these facts can be reasonably extrapolated to humans. In this stage, during which it was once believed that there was no exchange between the embryo and the mother, it is now known that there is a biological dialogue between mother and child of great importance. (Armant et al., 2000; Herrler et al. 2003; Kimber, 2000; Minas et al. 2005). This is an area of much interest in order to understand the factors that regulate implantation (Imakawa et al. 2004). Evidence in animals shows how the embryo regulates the immunological response of the mother to avoid rejection (Walker et al. 2010). The advance in knowledge about these factors can prove a useful tool in the treatment of sterility that is secondary to alterations in this process (Cakmak and Taylor, 2011).

\section{Bioethical remarks}

Bioethics (etymologically "ethics of life") offers an opportunity for dialogue between biological sciences and the humanities (philosophy, ethics, anthropology) to be able to address from an inter-disciplinary perspective the situations generated from biological knowledge that have social impacts. In this respect, Professor Claudio Barros encouraged this inter-disciplinary dialogue in our country to address the problem of when human life begins.

Although the biological sciences have unarguably demonstrated that the development of a new human being begins with fertilization, several countries have questioned that the life of an embryo before implantation be considered that of a new human being, deserving of respect as such. Other countries have gone further and have even affirmed that respect to a human being is conditioned by his/her state of development or capacity to fully express his/her potentials. For example, in the countries of the European Community it is considered that legally the human nature of the embryo is 
acquired at 14 days, given that at this point the nervous system of the embryo begins to manifest itself and the indivisibility of the embryo begins. For these countries, the human embryo is only a subject that merits respect at day 14 . Prior to that, the embryo is an "object" or "thing" (called a "pre-embryo) and consequently susceptible to manipulation, which supports therapeutic cloning through the use of stem cells.

There is no doubt that the embryo is implanted on day 7 and that it manifest the impossibility of division and of expressing its nervous system on day 14. These are only phases of a continued and ordered sequencing succession of biological events that began in the moment of fertilization. Consequently, these limits are arbitrary (Damschen et al. 2006; Gómez-Lobo, 2007). And with this, the use and destruction of pre-implantation human embryos has been justified. Life is a continuum, because of which if the life of a human being begins in the moment of fertilization, with the zygote "that houses all the necessary instructions for building a human body" (Lodish et al. 2008) such that it begins integrally, with its biological and spiritual components.

\section{CONCLUSIONS}

After a long road, the questions raised by the Greeks about the beginning of life and the process of generation of a new individual have taken us to clarifying life begins without any doubt in the moment of fertilization. The direct observation of this process by embryologists at the cellular level has been corroborated with fascinating discoveries at the molecular, genetic and epigenetic levels. We all begin, as Haeckel said "as a simple cell", but a cell that is a true organism that from its initial moment upon the fusing of the membranes of the spermatozoid and the ovum begins a coordinated activity clearly oriented to a determined development. Both the RNA inherited from the mother and the genes received from the father are activated through complex epigenetic mechanisms. From its first stages, the cells show a determined direction in a rich balance between regulation and plasticity. From the earliest stages, the generated child begins a rich exchange of signals with the mother that through an admirable coordination allows for the zygote's implantation in the mother's womb. Considering the panorama of human development, we add to the statement of Lodish and colleagues that this is not only an amazing feat, but also a wonderful and complex one. We believe that in these words we find the passion and dedication of Claudio Barros for research in this field.

At the opening, we stated that this issue has practical implications for the use and destruction of embryos in their first stage of development for therapeutic purposes, which is a question that has generated intense debates. This discussion is beyond the objective of our article, but does allow us to affirm that these debates are not in the biological plane about the beginning of life, but rather in the anthropological and ethical positions regarding the moral relevance of the human being at his/her beginning and consequently his/her dignity and right to be respected in his/her life, integrity and development.

Countries have taken different positions in relation to the legal status of the embryo. The Constitution in Chile protects all human beings without discrimination, including the unborn. In 2006 the Genome Law was passed, which deals with research into human beings and cloning. The Law specifies that the life and integrity of every human being must be protected from the moment of conception.

\section{ACKNOWLEDGMENTS}

This work was supported by the Concurso de Investigación para académicos UC 2009-2010. Pontificia Universidad Católica de Chile, Vicerrectoría Adjunta de Investigación y Doctorado (VRAID), Project \# 864-47.

\section{REFERENCES}

AO A, ERICKSON RP, WINSTON RM, HANDYSIDE AH. (1994) Transcription of paternal Y-linked genes in the human zygote as early as the pronucleate stage. Zygote 2:281-287.

ARISTÓTELES (2000) Movimiento de los animales, Introducción, traducción y notas de E. Jiménez Sánchez-Escariche y A. Alonso Miguel. Madrid Ed. Gredos. pp: 316.

ARISTOTLE (1953) Generation of Animals, 2nd ed. London - Cambridge (Ma): Heinemann - Harvard University Press, pp: I- XX.

ARMANT DR, WANG J, LIU Z (2000) Intracellular Signaling in the Developing Blastocyst as a Consequence of the Maternal-Embryonic Dialogue. Sem Reprod Med 18:v273-287.

AUERBACH L (1874) Zur Charakteristik und Lebensgeschichte der Zellkerne Breslau. Organologische Studien. Nabu Press. pp:347-348.

AUSTRIACO N (2006). The moral case or ANT-derived plutipotent stem cell lines. Natl Cathol Bioeth Quarterly 6: 517-537.

BARROS C, AUSTIN CR (1967) In vitro fertilization and the sperm acrosome reaction in the hamster. J Exp Zool. 166:317-323.

BARROS C, CROSBY JA, MORENO RD (1996). Early steps of sperm-egg interactions during mammalian fertilization. Cell Biol Int. 20:33-39,

BARROS C, FRANKLIN LE (1968). Behavior of the gamete membranes during sperm entry into the mammalian egg. J Cell Biol. 37:C13-C18.

BEDREGAL P, SHAND B, SANTOS MJ, VENTURA-JUNCÁ P (2010) Contribution of epigenetics to understand human development. Rev Med Chile 138:366-372.

BISCHOFF T (1854) Bestätigung des von Dr. Newport bei Betrachiern und Dr. Barry bei den kanichen behaupteten eindringens der Spermatozoiden in das Ei. (unknown binding).

BOVARI T (1890) Zellenstudien II: Ubre das Verhalten der chromatischen Kernsubstanz bei der Bildung der Richtungskörper und bei der Befruchtung. Jena. Zeit. Naturwiss. 24: 374.

BRADBURY J (2003) Human Epigenome Project-Up and Running. PLoS Biol. 1:E82-92.

BURGESS J. (2010) Could a zygote be a human being? Bioethics. 24:61-70

CAKMAK H, TAYLOR HS (2011) Implantation failure: molecular mechanisms and clinical treatment. Hum Reprod Update 17:242-253.

CAPANNA J (1999) Lazzaro Spallanzani: At the roots of modern biology, J Exper Zool 285:178-196

CARLSON BM (1994) Human Embryology and Developmental Biology. St. Louis: Mosby. pp:3.

CARRASCO MA,VENTURA-JUNCÁ P (2010) Urgencia de la Bioética ante la Biotecnología: ¿Cómo identificar un ser humano unicelular? Teología y Vida, LI: 179-231.

DAMSCHEN G, GÓMEZ-LOBO A, SCHÖNECKER D. (2006) Sixteen days? A reply to B. Smith and B. Brogaard on the beginning of human individuals. J Med Philos 31:165-175.

DANIELS R, LOWELL S, BOLTON V, MONK M (1997) Transcription of tissue-specific genes in human preimplantation embryos. Human Reprod 12:2251-2256,

EDDY EM, SHAPIRO BM (1979) Membrane events of fertilization in the sea urchin. Scan Electron Microsc 3:287-297.

EVANS JP, FLORMAN HM. (2002) The state of the union: the cell biology of fertilization. Nat Cell Biol. 4 Suppl: s57- s63.

FARLEY J (1982) Gametes \& Spores: Ideas about Sexual Reproduction, Baltimore (Md) and London: The Johns Hopkins University Press. pp: 60-75

FEIL R (2009) Epigenetic asymmetry in the zygote and mammalian development Int J Dev Biol 53:191-201.

FEINBERG AP (2008) Epigenetics at the Epicenter of Modern Medicine JAMA 299:1345-1350.

FIDDLER M, ABDEL-RAHMAN B, RAPPOLEE DA, PERGAMENT E (1995) Expression of SRY transcripts in preimplantation human embryos.Am J Med Genet 55:80-84, 
FLEMMING W (1880) Beiträge zur Kenntenis der Zelle und iherer Lebenserscheinungen, Arch MikroAnat 18:151-259.

FRANKLIN LE, BARROS C, FUSSELL EN (1970). The acrosomal region and the acrosome reaction in sperm of the golden hamster. Biol Reprod. 3:180-200.

GADELLA BM, EVANS JP (2011) Membrane fusions during Mammalian fertilization. Adv Exp Med Biol 713:65-80.

GILBERT S (2006) Developmental Biology. 8th ed. Sunderland (Ma): Sinauer Associates, Inc, pp:175-251..

GÓMEZ-LOBO A (2007) Individuality and human beginnings: a reply to David DeGrazia. J Law Med Ethics. 35:457-462.

GOOBWIN B (1993) Development as a Robust Natural Process, in STEIN W, VARELA FJ (eds) Thinking about Biology: An Invitation to Current Theoretical Biology. Reading, Mass: Addison-Wesley Publishing Co. pp:123-148;

HAECKEL E (1876) The evolution of man. Project Gutemberg (electronic version: http:// www.gutenberg.org/etext/8700.

HEMBERGER M, DEAN W, REIK W (2009) Epigenetic dynamics of stem cells and cell lineage commitment: digging Waddington's canal. Nat Rev Mol Cell Biol 10:526-537.

HERRLER A, VON RANGO U, BEIER HM (2003). Embryo-maternal signaling: how the embryo starts talking to its mother to accomplish implantation. Reprod Biomed Online 6:244-256,

HERTWIG O (1890) Verglich der Ei-und Samenbild bei Nematoden: Eine Grundlage dür celluäre Streitfragen Arch Mikro Anat 36:61.

HURLBUT WB, GEORGE RP, GROMPE M (2006) "Seeking Consensus: A Clarification and Defense of Altered Nuclear Transfer", Hastings Cent Rep. 36: 42-50.

IKEGAMI K, OHGANE J, TANAKA S, YAGI S, SHIOTA K(2009) Interplay between DNA methylation, histone modification and chromatin remodelling in stem cells and during development. Int. J. Dev. Biol. 53:203-214.

IMAKAWA K, CHANG KT, CHRISTENSON RK (2004) Pre-implantation conceptus and maternal uterine communications: molecular events leading to successful implantation. J Reprod Dev 50:155-169.

KIMBER SJ (2000) Molecular Interaction at the Maternal-Embryonic Interface During the Early Phase of Implantation, Sem Reprod Med 18: 237-253.

LANDER ES (2011) Initial impact of the sequencing of the human genome. Nature 470:187-197.

LARSEN, WJ. (1993). Human Embryology. New York: Churchill-Livingston. pp:1.

LINNAEUS C (1766) Systema Naturae Tomus I, Editio Duodecima, Reformata.. Tomus I. 12 editio (reformata). Homiae: Salvius. pp:1-532.

LODISH H, BERK A, KAISER CA, KRIEGER MP, SCOTT MP, BRETSCHER A, PLOEGH H, MATSUDAIRA P (2008) Molecular Cell Biology. 6th ed. New York, NY, W.H. Freeman \& Company. pp:12

MINAS V, LOUTRADIS D, MAKRIGIANNAKIS A (2005). Factors controlling blastocyst implantation. Reprod Biomed Online 10:205-216.

MOORE, KL, PERSAUD T (1993) The Developing Human, 5th ed. Philadelphia: W.B. Saunders Co. pp:1

NEEDHAM J A (1959) History of Embryology, New York, NY: AbelardSchuman. pp: 131.

NELSON H (1852) The Reproduction of the Ascaris. Phil Trans Roy Soc 142: 573-594.

NEWMAN S (2005) An Interview: Epigenetics vs. Genetic Determinism. Wild Duck Review Vol. V No. 2 In “Biotechnology" 1-8.
NEWPORT G (1853) On the impregnation of the ovum in the Amphibian and on the direct agency of the spermatozoon. Phil Trans Roy Soc. pp:270.

PEARSON, H (2002) Your destiny, from day one. Nature 418:14-15,

PLACHOT M (2000) Fertilization. Hum. Reprod. 15(Suppl. 4):19-30,

PREVOST J L ET DUMAS JB (1824) Deuxième mémoire sur la génération. Ann. Sci. Nat. $2: 129-149$.

PRIMAKOFF P, MYLES DG (2002) Penetration, adhesion, and fusion in mammalian sperm-egg interaction. Science. 296:2183-2185.

RAMALHO-SANTOS J, SCHATTEN G, MORENO RD (2002) Control of membrane fusion during spermiogenesis and the acrosome reaction. Biol Reprod. 67:1043-1051

SADLER TV (2000) Langman's Medical Embriology, Lippincott Williams \& Wilkins, pp:3.

SANTOS MJ (2005) Capítulo 26: Clonación Humana. In: GUZMÁN E, RODRÍGUEZ M RUIZ M (eds) Selección de temas en Ginecoobstetricia 1st ed. Santiago, Chile: Publiimpacto. pp: 473-482.

SANTOS, M.J (2006). Manipulación genética de seres humanos. Ars Médica $\mathrm{N}^{\circ} 13: 91-102$,

SCHULTZ, RM (1993) Regulation of zygotic gene activation in the mouse. BioEssays 15:531-538,

SCHWANN T (1874) Microscopical researches into the accordance in the structure and growth in of animals and plants trans. London: Henry Smith, pp:192.

SINGH M, CHAUDHRY P, ASSELIN E (2011) Bridging endometrial receptivity and implantation: Network of hormones, cytokines, and growth factors. J Endocrinol. Mar 3. [Epub ahead of print].

SMITH B, BROGAARD B (2003) Sixteen days. J Med Philos 28: 45-78,

SUTOVSKY P (2009) Sperm-egg adhesion and fusion in mammals. Expert Rev Molec Med 11:1-12,

SUTOVSKY P, MORENO RD, RAMALHO-SANTOS J, DOMINKO T, SIMERLY C, SCHATTEN G (1999). Ubiquitin tag for sperm mitochondria. Nature.; 402:371-372

SUTOVSKY P, VAN LEYEN K, MCCAULEY T, DAY BN, SUTOVSKY (2004) Degradation of paternal mitochondria after fertilization: implications for heteroplasmy, assisted reproductive technologies and mtDNA inheritance. Reprod Biomed Online 1:24-33.

VAN BENEDEN E. (1883) Recherches sur la maturation de l'oeuf et la fécondation. Arch Biol 4:610-620.

VENTURA-JUNCÁ P, SANTOS MJ, LARRAÍN J (2009) Proposals for Embryonic Stem Cell production without destroying Human Embryos: scientific and bioethical challenges. Acta Bioethics 15:222-233.

WALKER CG, MEIER S, LITTLEJOHN MD, LEHNERT K, ROCHE JR, MITCHELL MD (2010) Modulation of the maternal immune system by the pre-implantation embryo. BMC Genomics. 11:474.

WATSON J D, CRICK F (1953b) Genetic implications of the structure of deoxyribonucleic acid. Nature 171: 964-967.

WATSON J, CRICK F (1953a) Molecular structure of nucleic acids; a structure for desoxyribose nucleic acid. Nature 171:737-738.

WEISMANN A (1891) Amphimixis, or the essential meaning of conjugation and sexual reproduction. In: PULTON E, SHIPLEY AE (eds). Essays upon heredity, Oxford: Clarendon Press, pp: 121.

WHITAKER M (2006) Calcium at fertilization and in early development. Physiol Rev 86:25-88,

WU C, MORRIS JR (2001) Genes, genetics and epigenetics: a correspondence. Science 293: 1103-1105.

ZERNICKA-GOETZ M (2005) Cleavage pattern and emerging asymmetry of the mouse embryo. Nat Rev Mol Cell Biol 6:919-928. 
